\title{
The Effectiveness of Private Voucher Education:
}

\author{
Evidence from Structural School Switches
}

\author{
Bernardo Lara \\ Center for Applied Economics, Department of Industrial Engineering, \\ University of Chile
}

\author{
Alejandra Mizala* \\ Center for Applied Economics, Department of Industrial Engineering and \\ Center for Advanced Research in Education, University of Chile \\ Andrea Repetto \\ School of Government, Universidad Adolfo Ibáñez
}

This Version: November 20, 2009

First Version: April 5, 2009

\begin{abstract}
In this paper we analyze the effect of private voucher education on student academic performance using new data on Chilean students and a novel identification strategy. Most schools in Chile provide either primary or secondary education. We analyze the effect of private voucher education on students that are forced to enroll at a different school to attend secondary education once graduated from primary schooling -structural switches. Moreover the data set used in this paper contains information on previous academic achievement and thus allows us to identify differences in students' unobservable characteristics. Using a number of propensity score based econometric techniques and changes-in-changes estimation methods we find that private voucher education leads to small, sometimes not statistically significant differences in academic performance. The estimated effect of private voucher education amounts to about 4 to 6 percent of one standard deviation in test scores. The literature on Chile based on cross sectional data had previously found positive effects of about 15 to 20 percent of one standard deviation.
\end{abstract}

JEL Classifications: I200, I210.

Keywords: school choice, educational vouchers, school switches, student achievement, Chile.

\footnotetext{
* Corresponding author (e-mail:amizala@dii.uchile.cl). We thank Juan Pablo Atal, Julie Cullen, Eduardo Fajnzylber, Victor Lavy, Sergio Urzúa, Tomás Rau and participants at seminars at ILADES-Georgetown University, the Center for Applied Economics and the Economics Department at University of Chile, Universidad Adolfo Ibañez, and SECHI and LACEA Annual Meetings for comments and suggestions. We are grateful to the SIMCE office at Chile's Ministry of Education for providing us with the data and to Fernanda Melis, who helped us match the different data sources into a comprehensive database. Funding from Fondecyt (\#1070316 and \#1061224) and CONICYT Project CIE-05 Center for Advanced Research in Education is gratefully acknowledged.
} 


\section{Introduction}

One of the most important debates in educational policy relates to whether there should be a private market for the provision of education, the so called school choice debate (Hoxby, 2003). On the one hand, proponents argue that school choice generates competition, putting pressure on schools to improve the quality of both private and public education. On the other hand, critics argue that choice produces sorting, isolating the most disadvantaged students into low performing schools. The vast theoretical and empirical literature presents a mixed picture of the impact of school choice on student achievement.

Across countries, diverse initiatives have been undertaken in order to introduce choice into the educational system. Although residential choice is the most prevalent form of school choice in the United States, publicly and privately financed private voucher schools, open enrollment programs, charter schools and magnet schools coexist with traditional public schools. ${ }^{1}$ These experiences, though, cover a small number of mainly low income students. ${ }^{2}$ Outside the United States, Chile, Denmark, Netherlands, South Korea and Sweden are countries with universal voucher programs. There are also countries with targeted voucher programs, some related to geographical areas (Cote d'Ivoire and the Czech Republic) or to specific populations (Colombia, Guatemala, Puerto Rico and Pakistan).

The evaluation of the performance of these diverse forms of school choice is a difficult task. Switching to a voucher-type school might respond to the pursuit of higher school quality and peers or to shocks such as changes in family structure or employment opportunities (Hanushek et al, 2004). Moreover, under universality of the voucher, treatment and control groups are extremely hard to build. In fact, selection bias may arise because of both the choice

\footnotetext{
${ }^{1}$ Charter schools are public schools managed by a government appointed board with great administrative autonomy. Magnet schools are public schools that are allowed to attract students from outside zoned school boundaries by offering curriculum and pedagogical variety. They depend administratively on public school administration.

${ }^{2}$ According to Rouse and Barrow (2009), about 60 thousand students participate in a publicly-funded school voucher program in the US. There are about 100 thousand students enrolled in privately funded voucher programs. There are over 60 million school aged children in the States.
} 
of families who take advantage of the vouchers and may have unobserved characteristics that are correlated with academic achievement and the choice of schools and the manner in which they select their students (Cullen et al, 2005 and 2006, and Hsieh and Urquiola, 2006).

In this paper we study the effect of private voucher education on student performance using a new data set on Chilean students and a novel identification strategy. Specifically, the Chilean education system consists of eight years of primary school and four years of secondary school. Most schools financed by the governmental voucher have primary or secondary education only. In fact, about 64 percent of $8^{\text {th }}$ grade enrollees must switch schools at the end of the academic year to attend secondary education. This exogenous change allows us to compare the secondary school performance of students who moved from a public to a private voucher school with the secondary school performance of students that stayed in the public school system. In other words, the timing of structural switches is exogenous, allowing us to circumvent the phenomenon described as "Ashenfelter's dip" in the job training literature, i.e., selection on idiosyncratic temporary shocks (Ashenfelter, 1978).

Focusing on exogenous switches does not guarantee consistent estimators, however, because the assignment into different school types is not random. Limiting the analysis to students who attended primary education in a public school, together with the availability of new data, allow us to account for this problem. On the one hand, until recently only cross sectional data has been available on Chilean students, since national standardized achievement tests are administered annually to a specified grade level that rotates every year between the fourth, eighth, and tenth grades. In 2004 and 2006, however, the test was administered to the same students - in $8^{\text {th }}$ and $10^{\text {th }}$ grades, respectively. ${ }^{3}$ Although test scores are not comparable over time, the results of the students in 2004 can be used to identify

\footnotetext{
${ }^{3}$ Contreras and Santos (2009) analyze the relative performance of students at public and private subsidized schools using the same data base we use. Their estimates are based on a diff-in-diff approach. Unfortunately, their estimation method is not valid in this context, as tests scores are not comparable over time even after normalizing them, a strategy adopted by the authors.
} 
differences in students' unobservable characteristics when analyzing the 2006 results. On the other hand, primary school test scores reflect not only unobserved ability: they also reflect school type effects whenever the hypothesis that school type matters is true. So both controlling for pre-treatment achievement and limiting the sample to children attending the same types of schools in $8^{\text {th }}$ grade, help to better account for selection bias.

Based on this identification strategy we estimate the effect of private voucher school education relative to public school education for those students who were forced to find a new school at the end of $8^{\text {th }}$ grade. Specifically, in this paper we compare the $10^{\text {th }}$ grade performance of students who moved from a public to a private voucher school (treatment group) with the $10^{\text {th }}$ grade performance of students that stayed in the public school system (control group). That is, we estimate the effect of having attended two years of private voucher education after having attended a public school. In a sensitivity analysis, we also analyze the impact of structural moves from a private voucher school.

To estimate test score differences we use propensity score techniques and the changesin-changes (CIC) approach developed by Athey and Imbens (2006) that allows for differences in the distributions of unobservables across treatment and control groups.

Propensity score based estimates are positive for math and language tests, and are statistically significant in most cases. The results point to a 2.4 to 3.0 test score gain, i.e., a gain of 4 to 6 percent of one standard deviation. Although significant in statistical terms, our findings point at a difference between private voucher education and public education that does not seem economically relevant. Validity tests, as those suggested by Imbens and Wooldridge (2009), indicate that the identification strategy is most likely appropriate.

The changes-in-changes approach yields positive estimates of the same order of magnitude at the mean. Moreover, the results indicate that the effect on language test scores is positive for students in the full distribution of results, whereas the effect on math test scores is 
concentrated at the upper end of the outcomes' distribution. However, the results are not statistically significant.

Summing up, although based upon different theoretical assumptions about the underlying behavior of the data, propensity score type and changes-in-changes estimators yield similar results. The estimated effects are much lower than those obtained by the previous literature on Chile based on cross sectional data -which finds effects of private voucher education of about 0.15 to 0.2 standard deviations-, but in line with a number of papers on the United States' experiences that find small and many times ambiguous effects.

The paper is organized as follows: Section II reviews the previous literature on school choice. Section III provides a general overview of the Chilean educational system whereas Section IV explains our empirical strategy. Section V describes the data sources used in this study. Section VI presents our results. Finally, Section VII concludes.

\section{Previous Literature}

In this section we focus on the empirical evidence on the differences in the academic achievement of students attending private voucher schools relative to those attending public schools. There is a closely related literature on the effect of competition on public schools, including the literature on sorting, that we do not review here. ${ }^{4}$

In the United States there are several small-scale voucher programs, mostly designed for low-income students. ${ }^{5}$ Some are publicly funded, like the Milwaukee Parental Choice Program, the Cleveland Scholarship and Tutoring Program, and the Washington DC Opportunity Scholarship Program. Others are privately financed. From the public policy point

\footnotetext{
${ }^{4}$ Some studies analyze the impact of competition on public school students' achievement (see Hoxby, 2000 and 2003). Other papers study the effect of larger scale choice experiences, such as open enrollment within the Chicago Public School system, on students' outcomes, the degree of sorting and potential spillovers (see Cullen et al, 2005 and 2006).

${ }^{5} \mathrm{~A}$ review of the literature on the impact of private school vouchers can be found in Barrera-Osorio and Patrinos (2009), Belfield and Levin (2002), Hoxby (2003), Levin and Belfield (2003), McEwan (2004), Rouse and Barrow (2009), and Somers el al (2004).
} 
of view, publicly-funded vouchers can be more interesting since they have the potential of being extended into larger school voucher programs. In general, the research done to date analyzing these experiences finds relatively small achievement gains for students offered educational vouchers. Some of these results are not statistically different from zero.

The allocation of vouchers using a lottery in the aforementioned programs allows researchers to construct treatment and control groups to evaluate their impact on students' outcomes. However, since they rely on observational data they might be subject to omitted variable bias and thus potentially to unsatisfactory control groups. ${ }^{6}$ Aiming to overcome this shortcoming, the Washington DC program has been evaluated using a random assignment program design (Wolf et al, 2007 and 2008). Again the evidence suggests at most small improvements in the academic results of students who move to private schools thanks to the vouchers. Many studies do not find a statistically significant effect.

There are many privately funded vouchers programs. However, only three of them have been evaluated using a randomized design where applicants were selected at random to receive a voucher: the New York City, the Dayton Ohio and the Washington DC experiences. Two evaluations - Mayer et al (2002) and Krueger and Zhu (2004)- report small but not statistically significant impact when all students are included, and significant positive effects when considering only African American students (Howell and Peterson, 2002 and Mayer et al., 2002). However, the positive impact on these students is not robust. In particular, Krueger and Zhu (2004) argue that the results are sensitive to decisions related to sample and race definition.

A related literature studies the performance of charter schools based on the observed mobility of students across establishments. Following Hanushek et al (2004) that estimates the costs and benefits of mobility in regular public schools, Hanushek et al (2007) analyze the

\footnotetext{
${ }^{6}$ See Rouse (1998), Witte et al (1995), Witte (1997) and Greene et al (1998) for the Milwaukee program, and Metcalf (2001) and Belfield (2007) for the Cleveland case.
} 
Texas' charter experiment based on a panel of individual students that move across different schools, including charter schools. After controlling for student fixed effects to account for selection bias, Hanushek et al (2007) finds that after an initial start-up period, charter schools' performance is statistically similar to public schools' performance. The results also suggest that parents' of children attending charter schools seem more sensitive to quality in the decision of school switching. Using the same data set but a different set of indicator variables to account for school type and switches to and from charter schools, Booker et al (2004) find a significantly positive impact on students' academic achievement.

Outside the United States, the studies that have taken the advantage of a randomized design, like Angrist et al (2002 and 2006) for Colombia and Kang (2007) for South Korea, show that students that attend private vouchers schools experience a significant gain in achievement test scores. ${ }^{7,8}$ When vouchers are universal and have been in place for many years, however, more rigorous empirical strategies are difficult to implement. Research on countries like the Netherlands, Denmark and Sweden has focused on the effect of competition on students' outcomes. Barrera-Osorio and Patrinos (2009) review the empirical evidence on the effects of school choice on educational outcomes outside the United States and highlight that in the case of Denmark, studies do not find that competition improves educational achievement in public schools. In contrast in the case of Sweden higher competition has lead to improvements in the performance of public school students, and in the Netherlands, competition has been beneficial for all students.

Evaluations of the Chilean voucher system have focused on two issues: the relative effectiveness of private-voucher vis-à-vis public schools, and the effect of school competition

\footnotetext{
${ }^{7}$ The PACES program in Colombia was aimed to provide low-income students access to secondary private education. Since the program was oversubscribed, lotteries were performed to select voucher students. In South Korea students who finish elementary school are randomly assigned to public or private subsidized middle schools in their residential districts. The aim of the program is to generate homogeneity across schools within districts (Barrera-Osorio and Patrinos, 2009).

${ }^{8}$ Lavy (2009) uses differences in differences and a regression discontinuity design to evaluate school choice among public schools in Tel Aviv, Israel, to find large effects on students' outcomes. The paper also finds positive effects on behavioral outcomes, such as social acclimation in school and school violence.
} 
on student academic outcomes. Lacking randomized designs and panel data, researchers have addressed the first question by comparing the achievement of students who attend public and private schools with controls for their observed and -more tentatively- unobserved characteristics.

Given that data on socioeconomic characteristics was only available at the school level until 1997, early studies of relative effectiveness across school sectors used aggregate school averages. In general, all of the studies conclude that the socioeconomic characteristics of families are statistically significant in order to explain student performance in the different types of school. Nonetheless, when the performance of public and private schools is compared, the studies arrive at different conclusions. ${ }^{9}$

Availability of individual-level data since 1997 induced a new generation of studies that includes controls for students' resources and that attempts to account for selection. Most studies using individual-level data found that students attending voucher schools have higher educational outcomes than those from public schools; the estimated impact of these studies is typically between 0.15 and 0.2 standard deviations. Mizala and Romaguera (2001) and Sapelli and Vial (2002) estimate the effects on $10^{\text {th }}$ grade test scores. Using OLS and Heckman's two stage correction for selection bias respectively, both papers find effects of about 0.2 standard deviations. Sapelli and Vial (2005) use data on $4^{\text {th }}$ grade tests scores and Heckman (1979) methodology to find effects up to $40 \%$ of one standard deviation. More recently, Anand et al (2009) use propensity score matching to compare the test scores of reduced-fee paying, low-income students in private voucher schools to those of similar students in public schools and in free private voucher schools in Chile's Metropolitan Region. Their results reveal that students in fee-charging private voucher schools score higher - a test score gain of 0.2 standard deviations-, than students in public schools. The only paper that

\footnotetext{
${ }^{9}$ See McEwan and Carnoy (2000), Mizala and Romaguera (2000), Tokman (2002).
} 
finds no advantage of private voucher schools is McEwan (2001) which finds no consistent difference between public and non-religious private voucher schools, and a higher effectiveness of Catholic private-voucher schools.

Bravo et al (2008) use the 2002 and 2004 Social Protection Surveys (Encuesta de Protección Social, EPS) to estimate a dynamic model of schooling and working decisions. The advantage of the EPS is that it asks respondents to recall information on demographics, schooling and labor market attachment since the early 1980 s, before the voucher system was implemented. The paper concluded that the school voucher program induced individuals affected by the program to attend private voucher schools at a higher rate, to achieve higher educational attainment, to participate more in the labor force, and to perceive higher wages. The paper also found that returns to both public and private education increased after the introduction of school choice in Chile.

The second line of research has attempted to identify the effect of school competition on students' achievement. Hsieh and Urquiola (2006) found that private voucher schools “cream skim" students from more advantaged families, while relegating disadvantaged ones to the public sector. According to this study, given this sorting, the net aggregate effect of competition on student performance is negligible. On the other hand, Gallego (2002, 2006) and Auguste and Valenzuela (2003) found that greater competition significantly raises test scores. $^{10}$

At the heart of this debate is whether the data available and estimation strategies are enough to control for non-random selection of students into different school types and for unobservables that simultaneously impact both, the decision to attend a given school and

\footnotetext{
${ }^{10}$ There also exists a related literature that analyzes public and private school enrollment practices in response to vouchers (Elacqua, 2006). Other papers study whether private school networks have an academic advantage over public schools, once student characteristics, selectivity and peer attributes are controlled for (Elacqua et al, 2008). Finally, other papers analyze the socioeconomic stratification of achievement in the Chilean voucher system (Mizala and Torche, 2009).
} 
student's performance. In what follows we describe our identification strategy and discuss its advantages and limitations.

\section{The Chilean School System}

In the early 1980s, a military regime undertook sweeping reforms in many Chilean markets. The educational system was not an exception: a decentralization process transferred the administration of public schools to municipal governments, and the establishment of a voucher-type student-based subsidy paved the way for private sector participation as a provider of publicly financed education. ${ }^{11}$ The voucher, which is of the same size for both public and private voucher schools, is paid directly to schools on a per-student basis. The voucher is intended to cover running costs and generate competition between schools to attract and retain students, thus promoting more efficient and better quality education services. The monthly per student subsidy amounted to approximately $\$ 61.5$ for primary schools and $\$ 73.3$ for secondary schools in $2006 .{ }^{12}$

Three types of schools were established: public (municipal) schools, financed by the student-based subsidy granted by the State and run by municipalities; private voucher schools, financed by the subsidy and run by the private sector, and non-voucher private schools, financed by the tuition paid by parents and run by the private sector. There are no restrictions on the location of the schools the students can attend. Except for time constraints and other costs, students can travel to any part of a town or city to attend the school of their choice.

After the reform, a large number of new private schools willing to take the voucher were created. In 1985 there were 2,643 private voucher schools in Chile, a number that grew to almost 6,000 by 2006 . As a result, a massive migration from the public sector occurred. By

\footnotetext{
${ }^{11}$ Before the reform, there existed private-subsidized schools that were for free and funded by the government, but that received a lump-sum subsidy that was substantially smaller than the per-student spending in the public sector (Aedo, 2000).

${ }^{12}$ At an exchange rate equal to 530 Chilean pesos per US dollar.
} 
2006 private-voucher schools reached 44.0 percent of the enrollment, at the expense of the public sector, whose enrollment had dropped from 78 percent in 1981 to 47.7 percent in 2006 (Table 1). Enrollment in private-non voucher schools -about 7 percent of total enrollmentwas practically unaffected by the system's transformation. ${ }^{13}$

Non-voucher private schools are generally for profit, whereas private subsidized schools can be either for profit or non-for-profit. For-profit schools operate like private firms, generating returns for their owners. Elacqua (2006) estimates that about 70 percent of private voucher schools are for profits.

There are important differences in the regulation faced by private subsidized and public schools. First, private voucher schools can select their students while public schools are required to admit all students interested in enrolling. Only over-subscribed public schools are allowed to select students.

Second, the regulation of teacher contracts also differs, including the capacity to directly hire and dismiss teachers, which private subsidized schools have but public schools do not. As a matter of fact, teachers' contracts in public schools are governed by a special legislation -the Teachers' Statute- that involves centralized collective-bargaining as well as restrictions on teacher dismissal. Private schools, both subsidized and non-subsidized, operate as private firms, and their teachers come under the same Labor Code of other private sector workers in the country.

Finally, there are differences in the ability to raise alternative sources of financing. Initially voucher schools were not allowed to charge tuition to supplement the subsidy, but this restriction was eased in 1993. As of today, about 50 percent of private voucher schools charge tuition. Public schools are allowed to charge fees only at the secondary level, although in practice few of them do. In addition, public schools can receive subsidies from the

\footnotetext{
${ }^{13}$ A small portion of the school population attends schools run by educational corporations linked to business organizations.
} 
municipalities if the voucher is not enough to cover the entire budget; in fact, a number of municipalities transfer a significant amount of money to the schools. For this reason, authors such as Sapelli and Vial (2002) claim that some public schools face a soft budget constraint. Still, many municipalities transfer no funds at all.

The K-12 Chilean school system is divided into primary education (from kindergarten to $8^{\text {th }}$ grade) and secondary education (from $9^{\text {th }}$ to $12^{\text {th }}$ grade). Since 2003 both primary and secondary level education are mandatory. Almost all private non-voucher schools offer primary and secondary education. However, this is not the case for public and private voucher schools: 88 percent of public schools and 61 percent of private voucher schools offer primary education only. In terms of enrollment, in the year 2004, 64 percent of students had to switch schools at the end of the $8^{\text {th }}$ grade to continue to their secondary education, a fact that will be used as a part of our identification strategy below.

Table 1 provides some detail on the characteristics of private subsidized and public schools for year 2006. First, and although there is almost twice as many public schools than private subsidized schools in Chile, they represent similar shares of total enrollment. In addition, a small fraction of schools provide secondary education, which is much more prevalent in the municipal sector in terms of number of establishments. The differences in enrollment levels and shares correlate with the observed differences in class sizes across school types, with teachers at private voucher schools attending a larger number of students. Nevertheless, students enrolled in public schools belong to lower income households, receive fewer financial resources at school, and relate to peers of lower socio-economic backgrounds. These statistics show that there are relevant observable differences in the educational experiences of students attending different types of schools. 


\section{Identification Strategy and Estimation Methodologies}

This paper uses a new data set and a series of advanced econometric techniques to estimate the impact of a private-voucher school education on the students' scores in standardized achievement tests based upon a novel identification strategy.

As any paper that intends to identify treatment effects with a treated-nontreated formulation, this study faces the classical problem of only observing the post-treatment outcome in the observed treatment status. As in the usual Rubin model (Rubin, 1974), we only observe:

$$
Y_{i}=Y_{i 1} \cdot D_{i}+Y_{i 0} \cdot\left(1-D_{i}\right)
$$

where

$Y_{i}=$ Observed post-treatment outcome for individual $i$.

$Y_{i 1}=$ Post-treatment outcome for individual $i$ in case of receiving the treatment.

$Y_{i 0}=$ Post-treatment outcome for individual $i$ in case of not receiving the treatment.

$D_{i}=$ Dummy indicating whether individual $i$ did receive the treatment or not.

In other words, a major estimation problem faced is a missing data problem that is tackled by building counterfactuals. Another is selection bias. That is, we need to recognize that the observed assignment into different schools is not random.

In order to account for these estimation difficulties, we propose an identification strategy based on a common phenomenon that characterizes the Chilean educational market: the fact that most schools in Chile that are financed by the voucher provide either primary or secondary education only. In fact, in 2004,64 percent of the students enrolled in $8^{\text {th }}$ grade attended schools that did not provide secondary level education. These students had then to choose another school to continue studying. 
Until 2003, secondary schooling was not compulsory, only primary schooling was, thus limiting the size of the potential market. Also, cost concerns lead schools to narrow down to attending students in primary education only. The official secondary education curriculum requires that students are taught by teachers specialized in each subject. In contrast, for most of primary level education, a single teacher serves as the instructor for all subjects.

Our estimation strategy limits the analysis to the subsample of students that attended $8^{\text {th }}$ grade in a public school that provided no secondary education, and thus had to switch to another school in order to continue their education. Our treatment group is then composed of the students who moved to a private voucher school whereas our control group includes those who moved to another public school. Limiting the analysis to students who attended a public school in $8^{\text {th }}$ grade -instead of any school that did not provide secondary education-- improves the similarity between the treatment and control groups. In section VI we also provide the estimation results of limiting the analysis to students that were forced to switch schools but had attended a private voucher school in $8^{\text {th }}$ grade, using the same setup for building treatment and control groups. ${ }^{14}$

Another reason to limit the analysis to students attending public schools in 2004 is that although 2004 test scores allow us to control for unobserved student ability, these test results depend on the type of school the child attended up to eighth grade. In other words, under the hypothesis that school type matters, the correction for $8^{\text {th }}$ grade scores might not be enough to account for unobservable ability. So, limiting the analysis to this particular group of students allows for controlling for $8^{\text {th }}$ grade test scores that reflect pre-treatment achievement of students in control and treatment groups that had previously attended the same type of school.

Our identification strategy is based on a number of assumptions, and thus has advantages and shortcomings. In particular, some issues concern the generalizability of the

\footnotetext{
${ }^{14}$ The strategy of separating the samples depending on the type of school attended in $8^{\text {th }}$ grade and estimating the effects on both subsamples is an alternative approach to including all students that had to switch schools and controlling for school fixed effects.
} 
results. Because the effects are identified from structural school switches, it is an open question as to the extent that the estimates are relevant to students that attend schools that provide both, primary and secondary education. Moreover, our identification strategy leaves out from the analysis the students attending elite public schools, also known as "emblematic schools", which select students but enroll them earlier, in $7^{\text {th }}$ grade. If families who expect to receive higher benefits from attending these schools are more likely to enroll, our estimated effect may overstate the expected benefit to the average student. So the evaluation provides a consistent estimate of the benefit of the population that switches due to structural reasons at the end of $8^{\text {th }}$ grade only.

Another potential concern relates to the fact that some children might choose not to attend secondary education or to drop out. According to the Ministry of Education, a small fraction of students enrolled in secondary education in 2005 --4.8 percent-- dropped out in that same year. It is worth emphasizing that secondary schooling became mandatory starting in 2003 , forcing all students to continue their education once they earned the primary school certificate.

In what follows, we quickly review the estimators we use, their assumptions and properties. We use two types of econometric techniques: propensity score based estimators and changes-in-changes estimators.

\section{a. Propensity score based methodologies}

We use two propensity score based methodologies to identify the average treatment effect (ATE): propensity score weighting and the combination of the latter with regression adjustment (double-robust). The approach relies on the usual assumptions used in matching: unconfoundedness and overlap (Imbens and Wooldridge, 2009).

Assumption 1. Unconfoundedness 


$$
D_{i} \perp\left(Y_{i 0}, Y_{i 1}\right) \mid X_{i}
$$

where $X_{i}$ represents observable variables.

Assumption 2. Overlap

$$
0<\operatorname{pr}\left(D_{i}=1 \mid X_{i}=x\right)<1, \text { for all } x \text {. }
$$

The first assumption, also known as conditional independence, states that treatment assignment is exogenous given the covariates or the propensity score. ${ }^{15}$ The assumption means that participation in the treatment program does not depend on the outcome after controlling for differences in observed variables, such as socioeconomic status and performance in pre-treatment tests. It is a very controversial assumption (Imbens and Wooldridge, 2009), but still very popular, especially since Dehejia and Wahba (2002) showed good results in comparing experimental data and matching results in the evaluation of a training program.

The second assumption states that individuals should have positive probabilities of being observed in both treatment and control groups. This is less controversial and is likely to be accomplished by the construction of a common support.

The most popular of propensity score methodologies is propensity score matching. It consists of estimating the effect using as the counterfactual the observation with the closest propensity score value, allowing for the construction of control and treatment groups that are very similar in the probability of being treated. However, it is not clear how to estimate the standard errors in a way that takes into account clustering. ${ }^{16}$ In the case analyzed in this paper, it is very likely that there is clustering at the school level, so we would like to estimate correctly the variance of treatment effects. As far as we know, there is no method to correct

\footnotetext{
${ }^{15}$ Rosenbaum and Rubin (1983) showed the equivalence in the information contained in the vector of covariates and the propensity score in the unconfoundedness assumption.

${ }^{16}$ This concern also relates to modeling the selection process based on Heckman (1979) type methods.
} 
for clustered errors in the context of propensity score matching ${ }^{17}$. A popular option for taking into account clustered errors is bootstrapping at the cluster level; however, bootstrapping is not valid with matching ${ }^{18}$. Therefore, we focus on other propensity score based estimators that do not have these problems ${ }^{19}$.

Another propensity score based estimator of the average treatment effect is propensity score weighting. This method weights the observations using the propensity score and the treatment status. The idea is to balance the sample between treated and nontreated individuals based on the probability of treatment (Imbens and Wooldridge, 2009). Specifically, we use the inverse probability weighting (IPW) estimator proposed by Hirano, Imbens and Ridder (2003). Over this estimator we perform bootstrapping at the cluster level in order to estimate standard errors and confidence intervals. The bootstrapping procedure is performed before the construction of the propensity score and of the common support, taking into account potential errors in these procedures. $^{20}$

The other propensity score based method considered in this paper allows us to directly account for the correlation between covariates and outcomes. In particular, we expect the pretreatment test score to have a very strong and direct effect on the post-treatment test score. The method is the propensity score weighted regression, introduced by Robins and Rotnizky (1995), Robins et al (1995), and Robins and Ritov (1997). ${ }^{21}$ This method also has a doublerobustness feature: it provides consistent estimators if either the probability of treatment or the outcome regressions are incorrectly specified, implying some safeguard against model misspecification. Our implementation of the double-robust (DR) estimator follows the steps

\footnotetext{
17 Abadie and Imbens (2002) assume a diagonal conditional variance matrix for their matching variance estimation.

${ }^{18}$ Abadie and Imbens (2008) state that with matching the standard conditions of bootstrapping are not satisfied, and that the variance estimated using bootstrap diverges from the true variance.

${ }_{19}$ Despite the described problems, we estimated one-to-one propensity score matching to find a very similar ATE. Results are available upon request.

${ }^{20}$ Imbens (2004) argues that for regression and propensity score methods -- excluding propensity score matching-- bootstrapping is likely to lead to valid standard errors and confidence intervals.

${ }^{21}$ Further details on this method can be found in Imbens (2004) and Imbens and Wooldridge (2009). A generalization of this method is described in Wooldridge (2007).
} 
suggested by Emsley et al. (2008). To estimate the standard errors we again use bootstrapping at the school level, taking into account that errors might be correlated within schools.

The unconfoundedness assumption is a key assumption underlying these methods, but it is not directly testable. However, Imbens (2004) and Imbens and Wooldridge (2009) describe how to assess the plausibility of the assumption. A possibility consists on estimating the impact of the treatment on a variable correlated with the outcome of interest but that is not affected by the treatment. The authors suggest that a pre-treatment outcome closely related to the post-treatment outcome could play this role. The ideal variable is the pre-treatment value of the variable of interest. Fortunately, the $8^{\text {th }}$ grade test score fulfills this role within our subsample of students that attended a public school in $8^{\text {th }}$ grade. If the treatment had not been applied and the unconfoundedness assumption is valid, then propensity score methods should estimate zero impact on $8^{\text {th }}$ grade outcomes. Otherwise, it would indicate that there are unobservables that affect the outcome that would trick the researcher into stating that there is a treatment effect when there is not.

In our case, we define the score at $8^{\text {th }}$ grade $\left(Y_{8 t h}\right)$ as the dependent variable and as treatment the private school status at $10^{\text {th }}$ grade $\left(D_{10 t h}\right)$. We use as covariates the set of variables of $8^{\text {th }}$ grade $\left(X_{8 t h}\right)$ and estimate this "false experiment" using the same procedures (PSW and double-robust). In this manner, we verify whether $Y_{8 t h} \perp D_{10 t h} \mid X_{8 t h}$ holds. Nevertheless, it is worth emphasizing that finding no effect does not guarantee that $Y_{10 t h} \perp D_{10 t h} \mid X_{8 t h}, Y_{8 t h}$ is true, which is our main assumption, but it indicates that it is very likely the case.

\section{b. Changes-in-Changes Estimator (CIC)}

The alternative methodology implemented in this paper is the changes-in-changes estimator of the average effect of the treatment introduced by Athey and Imbens (2006). This 
estimator is a generalization of the difference-in-difference estimator, which needs fewer assumptions in order to obtain consistent estimations.

An important advantage of this methodology is that it allows for differences in the distributions of unobservables across treatment and control groups. Moreover, the estimator allows for the estimation of the treatment on any quantile of the unobservables distribution.

The main idea behind the estimator is that the distribution of unobservables of each group can be inferred from the pre-treatment outcomes. Once the distributions of unobservables of both groups are known, one can estimate how much of the observed effect is due to pre-treatment unobservables distribution differences.

More formally, the method compares group quantiles that had the same unobservable effects in the period before the treatment, assuming that quantiles that have the same rank of unobservables $U_{i}=u$ at time $t=0$, will have the same rank at $t=1$. This assumption allows the distribution of unobservables to differ across groups, but not over time. More specifically, according to Athey and Imbens (2006), the assumptions required to identify the treatment effect in a data set with the same individuals across time are the following ${ }^{22}$ :

Assumption 1. Model

The outcome of an individual in the absence of intervention satisfies the relation $Y^{N}=h(U, T)$.

Assumption 2. Strict Monotonicity

The production function $h(u, t)$, where $h: \cup \times\{0,1\} \rightarrow \mathbb{R}$, is strictly increasing in $u$ for $d$ $\in\{0,1\}$

Assumption 3. Rank Similarity within Groups

$U_{i 0}\left|D_{i}^{\sim} \stackrel{d}{\sim} U_{i 1}\right| D_{i}$

\section{Assumption 4. Support}

$\mho_{1} \subseteq \mho_{0}$

${ }^{22}$ Some of these assumptions are also discussed, in an educational context, in Angrist et al (2006). 
Assumption 3 requires that the rank within groups does not vary in arbitrary ways. It allows for a non-observable at time $t$ of the form

$$
U_{i t}=\varepsilon_{i}+v_{i t}
$$

with $\varepsilon_{i}$ a time invariant individual specific unobserved component (fixed effect), and $v_{i t}$ an idiosyncratic error term with the same distribution in both periods. Assumption 4 is made in order to identify the treatment on the treated effect. However, in order to obtain the ATE, we also need $\mho_{1} \supseteq \bigcup_{0}$. Both are accomplished by the construction of a common support for nonobservables.

Athey and Imbens (2006) also propose a CIC estimator with controls for covariates. The procedure is done in two stages. After defining the vector of group dummy variables (indicating treated and controls) and the covariates $X$, the first step consists of estimating through OLS (without a constant) the equation

$$
Y_{i t}=D_{i}{ }^{\prime} \delta_{t}+X_{i t}{ }^{\prime} \beta_{t}+\varepsilon_{i t}
$$

and of constructing the residuals in the following way:

$$
\hat{Y}_{i}=Y_{i}-X_{i}{ }^{\prime} \hat{\beta}=D_{i}{ }^{\prime} \hat{\delta}+\hat{\varepsilon}_{i}
$$

Then, the second step consists of applying the CIC estimator to the residuals obtained in the last equation, which means that the estimation is based upon the part of the variation in the dependent variable that observables do not explain. If the assumptions are correct, this provides us with a consistent and asymptotically normal estimator. Again, we use bootstrapping at the school level to estimate clustered errors.

Finally, it is worth emphasizing that the CIC approach is built in order to accomplish the validity test of the unconfoundedness assumption described above, as it compares the quantiles that exactly fulfill $Y_{8 t h} \perp D_{10 t h} \mid X_{8 t h}$, since they have the exact same unobservable effect in $8^{\text {th }}$ grade. 


\section{Data}

The empirical data used in this study come primarily from two sources. The first source is a standardized test called the SIMCE (Sistema de Medición de la Calidad de la Educación, Education's Quality Measurement System), which is administered annually throughout Chile to a specified grade level that rotates every year between the $8^{\text {th }}$ and $10^{\text {th }}$ grades, and starting in 2005 , every year to $4^{\text {th }}$ grades. This rotation implies that, except for the case of the data used in this paper, the SIMCE tests do not track students over time.

This paper uses the 2006 SIMCE data which was administered to $10^{\text {th }}$ graders. Because the 2004 SIMCE test was administered to $8^{\text {th }}$ graders, for the first time we also have data on student previous performance, allowing us to better control for unobserved characteristics, and to form new treatment and control groups. Specifically, we take advantage of the fact that the majority of Chilean students mandatorily changes school at the end of the $8^{\text {th }}$ grade, the last year of primary school, given the way that the educational system is organized. However, it is important to note that our data set cannot be analyzed as a panel, as SIMCE scores are not comparable across tests.

One limitation of working with data on older students --instead of $4^{\text {th }}$ graders, for instance-- is that ability based selection is easier among students in higher grades, since at this point in life, schools have more information on the students' academic abilities as they can track their records.

The second data source is a questionnaire that is answered by the parents of students that participated in the SIMCE in 2004 and 2006. This questionnaire provides information on the socio-economic characteristics of each student, such as their family income and parents' 
education. Although it is not mandatory for parents to complete the questionnaire, there is a high response rate for most of the key variables used in this analysis. ${ }^{23}$

Once these data sources were combined into a comprehensive database and after excluding those with incomplete information, several modifications were made to target the population that we are interested in studying. First, according to our identification strategy we only consider the subsample of students who were forced to switch schools after they finished their primary education. Second, we exclude students in private non-voucher schools from the analysis because these schools typically serve only the most elite families in Chile. Private non-voucher schools are not a realistic educational option for the average student in Chile because the typical fee charged at private non-voucher schools is over three times the perstudent voucher paid by the state and much higher than the cost of attending a fee-charging private voucher school. Finally, we only consider students that attend urban schools, since in rural areas students have limited school choice as a result of geographic and other constraints. $^{24}$

In addition, about 12 percent of students that had to switch school between the $8^{\text {th }}$ and $9^{\text {th }}$ grades declare to have switched again between the $9^{\text {th }}$ and $10^{\text {th }}$ grades. Unfortunately, we do not know which school type they attended in $9^{\text {th }}$ grade. Given this data limitation, we have excluded these students from the analysis. ${ }^{25}$

Modifications were also made to some of the variables in the database in order to make them compatible with our analysis. For example, on the parental questionnaire, parents reported the highest level of education that they had attended. These levels were converted into the corresponding number of years they had been in formal education: the maximum time

\footnotetext{
${ }^{23}$ To perform our analysis, we only use the observations that have complete information; no data is imputed for missing observations.

${ }^{24}$ Currently, 63 rural municipalities out of a total of 345 municipalities do not have private voucher schools.

${ }^{25}$ Since this sample decision might induce a sample selection bias as the choice to switch again might be correlated with achievement, we also estimated our models including these students to find similar estimated effects. Results are available from the authors upon request.
} 
a parent could spend in basic education is 8 years, high school is 12 years, professional school or technical institute is 16 years, college is 17 years, a master's degree is 19 years, and a doctoral degree is 22 years. Parents also reported their monthly income as a range (for example, a parent could report that their income is between 400,000 to 500,000 pesos). These ranges were replaced with the midpoint, which means in the prior example the parent would have an income of $450,000 \operatorname{pesos}^{26}$. Furthermore, the income was divided by 1,000 to simplify the interpretation of results.

Appendix Table A1 provides a complete list of variables used in this paper, along with their definition and data source. Table 2 summarizes the basic statistics for the sample used in this study, i.e., students that completed $8^{\text {th }}$ grade in a public school and had to switch schools to pursue secondary education. ${ }^{27}$ On average, without controlling for student or school-level characteristics, those who switched to private voucher schools tend to score better than students who moved to public schools. They also have better resources: parents with higher education levels, higher family income, and parents with higher expectations about the education level their sons and daughters will attain. Moreover, a lower percentage of students who moved to private vouchers schools had repeated a grade and a higher percentage had preschool education than those who switched to public schools.

\section{Results}

We estimate the effect of private voucher education on student performance using alternative estimation methods. We first analyze the results using propensity score methods and then the CIC approach. The estimators presented in this section are based on different assumptions on the manner students select themselves into school types. Propensity score-

\footnotetext{
${ }^{26}$ The Chilean distribution of income is quite flat until the $90^{\text {th }}$ percentile is reached. We expect that using the midpoint of the range does not lead to relevant biases in the definition of family income.

${ }^{27}$ Tables A2 and A3 in the Appendix present the basic statistics for the sample of students who completed $8^{\text {th }}$ grade in a private voucher school and had to switch schools, and for all students who had to switch school after $8^{\text {th }}$ grade, respectively.
} 
type estimators assume selection on observables, whereas the CIC approach allows for observables and unobservables but assumes that the within group distribution of unobservables remains constant over time.

\section{a. Propensity score based methods}

We first estimate the probability of attending a private voucher school; i.e., the propensity score. In the model we include the relative supply of private voucher schools in the students' neighborhood of residence, student-level characteristics and pre-treatment SIMCE test scores, all measured in 2004. The results are displayed in Table 3. They show that income, maternal education and parental expectations on attending post secondary education are correlated with a higher likelihood of attending private voucher schools. On the contrary, students who have repeated a grade are less likely to attend private voucher schools. Also, students are more likely to enroll in private voucher schools whenever there are more private voucher schools in the neighborhood. Finally, the estimation results show no significant statistical correlation between the probability of treatment and the students' past score in the standardized tests.

Figures $1 \mathrm{a}$ and $1 \mathrm{~b}$ show the densities of the estimated propensity scores by both school type and subject test. These densities display a very similar mode; i.e., the difference in the mode of the treatment probability density is only 5 percentage points. The densities also display a common support. ${ }^{28}$

Table 4 presents ATE estimates using propensity scores based methods and validity tests. Using propensity score weighting we obtain positive effects that are statistically

\footnotetext{
${ }^{28}$ We constructed the common support by dropping the observations of the control (treatment) group that had propensity scores below (above) the minimum (maximum) propensity score of the treatment (control) group. Only 7 observations were dropped according to this criterion. In addition, the weighting estimators might give too much weight to some observations. The individual with the highest weight represented only 0.05 percent of the sample, so no additional observations were dropped when estimating the IPW. However, a cutoff of a 5 percent weight was used in the bootstrap procedure. That is, all resampling observations with weights above 5 percent of the iteration samples were dropped from the bootstrap estimations.
} 
significant at a 1 percent for language and at 5 percent for math tests, respectively. Similar results are obtained using propensity score weighted regressions (double robust), with statistical significance ranging between 1 percent and 10 percent. The estimated effect of private voucher education amounts to 2.36 to 3.02 points in the standardized achievement test, i.e., 4 to 6 percent of one standard deviation in test scores, an effect much smaller than the one found in the previous literature on Chile. ${ }^{29}$

We now proceed to estimate the validity tests proposed by Imbens and Wooldridge (2009). We first estimate the propensity score without controlling for the pre-treatment test score. The results of the probit estimation are shown in Table A4 in the appendix. We then use the estimated propensity score to assess the effect of the treatment on $8^{\text {th }}$ grade test scores, using the same weighting techniques as before (IPW and double-robust). The results are presented in the right hand side panel of Table 4 . These tests find no effect of the $10^{\text {th }}$ grade treatment on $8^{\text {th }}$ grade scores. These results suggest that there are no relevant unobservable variables in the pre-treatment period and thus unconfoundedness is accomplished in $8^{\text {th }}$ grade. These results in turn imply that it is highly likely that our strategy accounts for unobservables in the post-treatment period.

\section{b. CIC estimators}

Table 6 presents the results obtained using CIC estimation methods without and with controls for covariates, respectively, as proposed by Athey and Imbens (2006). ${ }^{30}$ The estimated effect of private voucher education is slightly lower than the one obtained using

\footnotetext{
${ }^{29}$ Similar results are obtained when estimating a different specification of the probability of attending a private voucher school. This alternative specification also includes school characteristics (school size and per pupil resources), the reasons parents listed for choosing the school the students attended in $8^{\text {th }}$ grade and controls for the motivation and involvement of the parents in the education of their children (participation in PTA meetings, and number of times they talk to the teachers). Results are available upon request.

${ }^{30}$ The covariates used to estimate CIC with controls are parental education, family income, number of household members, student's gender, whether the child repeated a grade, whether the child attended preschool, and the number of books at home.
} 
propensity scores based econometric technique, ranging from 1.34 to 1.87 points. However, the estimated effects turn out to be not statistically significant in all cases.

The CIC methodology allows us also to infer the effect of the treatment on the entire distribution of students. Figures $2 \mathrm{a}$ and $2 \mathrm{~b}$ present the results after correcting for covariates. Figure $2 \mathrm{a}$ shows that all students above the $35^{\text {th }}$ percentile of the distribution of math test scores experience positive effects of attending private voucher education. For language test scores, the positive effects are evenly distributed along the distribution of results. That is, according to the CIC estimates, not only the average student is benefited by private voucher school education but also most students along the distribution of outcomes. However, none of these estimates are statistically significant.

Summing up, if our identification strategy based on the analysis of the subsample of students who were forced to switch schools is valid, then the estimators suggest that there are small differences in the performance of students attending private voucher and public schools that tend to favor the former.

\section{c. Sensitivity analysis}

As an extension of our identification strategy we re-estimate the effect of private voucher education now limiting the subsample to those students who attended $8^{\text {th }}$ grade in a private voucher school that provided no secondary education, and thus had to switch to another school in order to continue their education. Then our new control group is composed of the students who moved to a public school whereas our treatment group includes those who moved to another private voucher school.

Table 7 presents the results for propensity score based methods and the CIC approach. In the case of language SIMCE test scores, the estimated effect is in most cases negative, ranging from -1.23 to 0.61 points. In the case of math SIMCE test scores, the effect is positive 
ranging from 1.81 to 3.49 points in the test. However, none of the estimated results are statistically significant. $^{31}$

The right hand panel of Table 7 presents the validity tests proposed by Imbens and Wooldridge (2009). The statistics suggest a significant effect of the treatment on $8^{\text {th }}$ grade scores, increasing the likelihood that the transition from private voucher to public schools is an endogenous phenomenon. In other words, the unconfoundedness assumption is unlikely to hold in this setup. This means that students who moved from a private voucher to a public school may be different in unobservable ways from those who moved to another private voucher school. For instance, one possible reason for this result is that the students who finished primary school in a private voucher school, and changed to a public school, opted mainly for a high achievement public school. These schools have excess demand and thus can select high-ability students.

\section{Discussion and Concluding Remarks}

In this paper we revisit the school choice debate using new data on Chilean students and a new identification strategy. Specifically, we examine the differences in the $10^{\text {th }}$ grade standardized test performance of students who moved from a public to a private voucher school (treatment group) with the $10^{\text {th }}$ grade standardized test performance of students that stayed in the public school system (control group).

With these groups at hand, we estimate test score differences using propensity score techniques and the changes-in-changes approach developed by Athey and Imbens (2006). Propensity score techniques lead to positive and many times statistically significant effects for both math and language tests. Moreover, validity tests for the unconfoundedness assumption are passed. In addition, the changes-in-changes approach suggests that these positive effects

\footnotetext{
${ }^{31}$ The descriptive statistics of these students and the model that estimates the probability of attending a private voucher school are presented in Tables A2 and A5 of the Appendix, respectively.
} 
apply to the full distribution of results in the case of language scores and to the upper part of the distribution in the case of math scores, i.e., they are not concentrated within a particular group of students. However, these latter estimates are not statistically significant. In sum, although based upon different theoretical assumptions about the underlying behavior of the data, propensity score type and changes-in-changes estimators yield similar results.

The statistical significance of our results contrasts with their economic relevance as the private voucher education effect we find is never larger than 6 percent of one standard deviation. Different hypothesis might explain why the estimated effect is small. One possibility is that competition does put pressure on both types of schools, leading them to achieve similar academic results.

Alternatively, private voucher schools might not be motivated enough to provide better academic results. In fact, the current Chilean school system regulation is lax, allowing schools to survive even if the academic performance of their students is poor. To continue participating in the voucher system, private schools have to meet minimal standards, and there is no supervision on how public resources are spent. Consequently, very few schools close in Chile. As a matter of fact, an educational system reform recently passed into law a regulation that will put higher academic pressure on schools financed by public resources.

A complementary reason might be that private and public schools do compete, but in dimensions other than academic achievement. A possibility is that parents care about peer socioeconomic makeup in itself, regardless of achievement (Elacqua et al., 2006, Hsieh and Urquiola, 2006). Alternatively, parents do care about school achievement and are able to assess average school performance; but given the strong correlation between socioeconomic status and students' performance, they cannot assess the value added by the school (Mizala et al., 2007). This is consistent with the scant evidence of students switching to more effective schools (Mizala and Urquiola, 2008). 
Another hypothesis is that the treatment we measure does not allow for enough exposure of students to private voucher education. Recall that the evaluation is done after only two years of private education. Thus, our results could be reinterpreted as a gain of 4 to 6 percent of one standard deviation in a two year period, which is in line with the estimated 1.5 to 2.3 percent of a standard deviation gain per year in math test scores that Rouse (1998) reported in the case of students selected for the Milwaukee Parental Choice Program.

In addition, the results are representative of students who have attended public schools up to the $8^{\text {th }}$ grade - at 14 years of age on average. Perhaps, at this stage it is too late to generate significant changes in the academic achievement of students.

Finally and as a consequence of our non-experimental approach, our results may be explained by potential biases introduced by our identification strategy if it is not fully able to control for non-random selection of students into different school types and for unobservables that affect school choice and performance at the same time.

Although this paper has dealt with the case of Chile, we believe the methods and identification strategy are a useful approach to analyze a wide variety of school choice experiences performed in other countries. 


\section{References}

Abadie, A., and G. Imbens (2008), "On the Failure of the Bootstrap for Matching Estimators," Econometrica, Vol. 76 (6): 1537-1557.

Abadie, A., and G. Imbens, (2002), "Simple and Bias-Corrected Matching Estimators for Average Treatment Effects," Technical Working Paper T0283, NBER.

Aedo, R. (2000), “La Educación privada en Chile: Un estudio histórico-analítico desde el periodo colonial hasta 1990". Santiago: RIL Editores.

Anand, P., Mizala, A. and A. Repetto (2009), "Using School Scholarships to Estimate the Effect of Government Subsidized Private Education on Academic Achievement in Chile," Economics of Education Review, Vol 28: 370-381.

Angrist, J. D., Bettinger, E., Bloom, E., King, E. and M. Kremer. (2002). "Vouchers for Private Schooling in Colombia: Evidence from a Randomized Natural Experiment," American Economic Review, Vol. 92(5): 1535-1558.

Angrist, J. D., Bettinger, E. and M. Kremer (2006), "Long term educational consequences of secondary school vouchers: evidence from administrative records in Colombia" American Economic Review, Vol 96(3): 847-862.

Ashenfelter, O. (1978), "Estimating the Effect of Training Programs on Earnings," Review of Economics and Statistics, Vol. 60(1): 47-57.

Athey, S. and G. Imbens. (2006). "Identification and Inference in Nonlinear Difference-inDifferences Models." Econometrica, Vol. 74(2): 431-97.

Auguste, S. and J.P. Valenzuela (2003). "Do students benefit from school competition? Evidence from Chile”, Mimeo, University of Michigan.

Barrera-Osorio, F. and H. Patrinos (2009). "An international perspective on school vouchers" mimeo World Bank.

Belfield, C.R. (2007). "Achievement effects of the Cleveland Scholarship and Tutoring Program” Working Paper Dept. of Economics Queen's University

Belfield, C.R. and H. Levin (2002). "The effects of competition between schools on educational outcomes: A review for the United States" Review of Educational Research Vol 72(2): 279-341.

Booker, K., Gilpatric, S., Gronberg, T. and D. Jansen (2004). "Charter School Performance in Texas" Private Enterprise Research Center Working Paper, Texas A\&M University. 
Bravo, D., Mukhopadhyay, S. and P. Todd (2008). "Effects of a universal school voucher system on educational and labor market outcomes: Evidence from Chile" mimeo Department of Economics, University of Pennsylvania.

Cullen, J., Jacob, B. A. and S. D. Levitt, (2005). "The impact of school choice on student outcomes: an analysis of the Chicago Public Schools" Journal of Public Economics 89(5-6):729-60.

Cullen, J., Jacob, B.A. and S. D. Levitt, (2006). “The Effect of School Choice on Student Outcomes: Evidence from Randomized Lotteries" Econometrica. 74(5): 1191-1230.

Dehejia, R.H, and S. Wahba (2002), "Propensity Score Matching Methods for NonExperimental Causal Studies," Review of Economics and Statistics, Vol. 84(1): 151-161.

Elacqua, G., Schneider, M. and J. Buckley. (2006). "School choice in Chile: Is it class or the classroom? Journal of Policy Analysis and Management Vol. 25(3).

Elacqua, G. (2006). "Public, Catholic, and for-profit school enrollment practices in response to vouchers: Evidence from Chile". National Center for the Study of Privatization in Education, Teachers College, Columbia University, paper 125

Emsley, E., M. Luna, A. Pickles and G. Dunn (2008). "Implementing double-robust estimators of causal effects," Stata Journal, Vol. 8(3), pages 334-353.

Gallego, F. (2002). “Competencia y resultados educativos: teoría y evidencia para Chile”, Cuadernos de Economía 39(118): 309-352.

Gallego, F. (2006). "Inter-school competition, incentives and outcomes: Evidence from Chile", mimeo Department of Economics, MIT, USA.

Greene, J.P., Peterson, P.E. and J. Du (1998). "School Choice in Milwaukee: A Randomized Experiment," P.E. Peterson and B.C. Hassel (eds) Learning from School Choice, pp. 335-356, Brookings Institute, Washington DC.

Hanushek, E., Kain, J. and S. Rivkin (2004). "Disruption versus Tiebout Improvement: The Costs and Benefits of Switching Schools", Journal of Public Economics 88(9): 17211746.

Hanushek, E., Kain, J., Rivkin, S. and G. Branch (2007). "Charter School Quality and Parental Decision Making With School Choice." Journal of Public Economics, Vol. 91(5-6): 823-848.

Heckman, J. (1979), "Sample selection bias as a specification error", Econometrica, Vol. 47, pp.153-61.

Hirano, K., Imbens, G. and G. Ridder (2003). "Efficient Estimation of Average Treatment Effects Using the Estimated Propensity Score,” Econometrica, Vol. 71(4), 1161-1189. 
Howell, W. and P.E. Peterson (2002). The Education Gap: Vouchers and Urban Schools, Brookings Institute, Washington DC.

Hoxby, C. (2000). "Does competition among public schools benefit students and taxpayers? American Economic Review 90(5):1209-1238.

Hoxby, C. (2003). "School Choice and School Productivity (or Could School Choice be a Tide that Lifts All Boats?" In C. Hoxby (ed) The Economics of School Choice, Chicago University Press.

Hsieh, C. and M. Urquiola, (2006). "The effect of generalizad school choice on achievemnet and stratification: Evidence from Chile's school voucher program" Journal of Public Economics, 90, 1477-1503.

Imbens, G.W. (2004). "Nonparametric estimation of average treatment effects under exogeneity: a review." Review of Economics and Statistics, Vol 86(1): 4-29.

Imbens, G.W. and J. Wooldridge (2009), "Recent Developments in the Econometrics of Program Evaluation” Journal of Economic Literature, 47(1): 5-86.

Kang, C. (2007). "Classroom peer effects and academic achievement: Quasi-randomized evidence from South Korea". Journal of Urban Economics 61(3): 458-495

Krueger, A. and P. Zhu (2004). "Another Look at the New York City School Voucher Experiment," American Behavioral Scientist Vol 47: 699-717.

Lavy, V. (2009), "Effects of Free Choice among Public Schools," Review of Economic Studies, forthcoming.

Levin, H. and C.R. Belfield (2003). "The marketplace in education" Review of Research in Education, Vol. 27(1), 183-219

Mayer, D. P., Peterson, P. E., Myers, D. E., Tuttle, C. C., and W. G. Howell (2002). "School Choice in New York City After Three Years: An Evaluation of the School Choice Scholarships Program” (No. 8404-045): Mathematica Policy Research, Inc.

Metcalf, K. (2001). "Evaluation of the Cleveland Scholarship and Tutoring Program, Summary Report 1998-2002" Indiana Center for Evaluation and Educational Policy.

McEwan, P. (2004). “The Potential Impact of Vouchers", Peabody Journal of Education 79(3): 57-80

McEwan, P.J. and M. Carnoy (2000). "The Effectiveness and Efficiency of Private Schools in Chile's Voucher System", Educational Evaluation and Policy Analysis, 33: 213-239.

McEwan, P.J (2001). "The Effectiveness of Public, Catholic, and Non-Religious Private Schools in Chile's Voucher System," Education Economics, Vol. 9(2): 103-128. 
Mizala, A. and P. Romaguera, (2000). "School Performance and Choice: The Chilean Experience", Journal of Human Resources 35(2): 392-417.

Mizala, A. and P. Romaguera, (2001). "Factores explicativos de los resultados escolares en la educación secundaria en Chile", El Trimestre Económico 272: 515-549.

Mizala, A., Romaguera, P. and M. Urquiola (2007). "Socioeconomic status or noise? Tradeoffs in the generation of school quality information", Journal of Development Economics 84: 61-75.

Mizala, A. and F. Torche (2009). "Bringing the Schools Back In: The Stratification of Educational Achievement in the Chilean Voucher System”, Mimeo Center for Applied Economics, University of Chile.

Mizala, A. and M. Urquiola (2008). "School Markets: The Impact of Information Approximating Schools' Effectiveness”, NBER Working Paper 13676

Robins, J. M., and Y. Ritov (1997). "Toward a Curse of Dimensionality Appropriate (CODA) Asymptotic Theory for Semi-parametric Models", Statistics in Medicine, Vol. 16(3): $285-319$.

Robins, J. M., and A. Rotnitzky (1995). "Semiparametric Efficiency in Multivariate Regression Models with Missing Data." Journal of the American Statistical Association, Vol. 90(429): 122-29.

Robins, J. M., A. Rotnitzky, and L. P. Zhao (1995). “Analysis of Semiparametric Regression Models for Repeated Outcomes in the Presence of Missing Data." Journal of the American Statistical Association, Vol. 90(429): 106-21.

Rosenbaum, P.R., and D.B. Rubin (1983), "The Central Role of the Propensity Score in Observational Studies for Causal Effects," Biometrika 70: 41-55.

Rouse, C.E. and L. Barrow (2009), "School vouchers and student achievement: Recent evidence, remaining questions" Annual Review of Economics vol 1.

Rouse, C.E. (1998). "Private School Vouchers and Student Achievement: An Evaluation of the Milwaukee Parental Choice Program," Quarterly Journal of Economics, 113: 553602.

Rubin, D.B. (1974). "Estimating Causal Effects of Treatments in Randomised and NonRandomised Studies.” Journal of Educational Psychology, Vol. 66(5), 688-701.

Sapelli, C. and B. Vial (2002). "The performance of private and public schools in the Chilean voucher system" Cuadernos de Economía 39(118): 423-454. 
Sapelli, C. and B. Vial (2005). "Private vs public voucher schools in Chile: New evidence on efficiency and peer effects" Working Paper N 289 Instituto de Economía, Catholic University of Chile.

Somers, M.A., McEwan, P.J. and D. Willms (2004). "How Effective are Private Schools in Latin America?" Comparative Education Review, 48: 48-69.

Tokman, A. (2002), "Is Private Education Better? Evidence from Chile." Central Bank of Chile Working Paper $\mathrm{N}^{\mathrm{o}} 147$.

Witte, J. (1997). “Achievement effects of the Milwaukee voucher program.” Working Paper University of Wisconsin at Madison.

Witte, J., Thorn, CA and OD Sterr (1995). "Fifth year report: Milwaukke Parental Choice Program" Working Paper University of Wisconsin at Madison.

Wolf, P., Gutmann, B., Puma, M., Rizzo, L, Eissa N., and M. Silverberg. (2007). "Evaluation of the D.C. Opportunity Scholarship Program: impacts after one year" US Department of Education, Institute of Education Science

Wolf, P., Gutmann, B., Puma, M., Kisida, B., Rizzo, L and N. Eissa. (2008). "Evaluation of the D.C. Opportunity Scholarship program. Impacts after two years". US Department of Education, Institute of Education Science.

Wooldridge, J. (2007). “Inverse Probability Weighted M-Estimation for General Missing Data Problems" Journal of Econometrics 141:1281-1301. 


\section{Table 1}

\section{Private Subsidized vs Public Schools' Characteristics in 2006}

\begin{tabular}{lcc} 
& Public & $\begin{array}{c}\text { Private } \\
\text { Voucher }\end{array}$ \\
\hline Number of schools & 10,928 & 5,924 \\
Number of schools that provide secondary education & 2,483 & 682 \\
\% of schools that provide secondary education & $22.7 \%$ & $11.5 \%$
\end{tabular}

Total enrollment $1,539,465 \quad 1,417,992$

Secondary school enrollment $454,013 \quad 457,938$

Total enrollment share $47.7 \% \quad 44.0 \%$

Secondary school enrollment share

$43.6 \% \quad 43.9 \%$

Students per teacher

Students per teacher in secondary education

Monthly resources per student (dollars)

Mothers' years of education

Fathers' years of education

$9.3 \quad 11.0$

Monthly household's income (dollars)

413

672

Sources: Ministry of Education, 2006 SIMCE data base and Central Bank of Chile. The 2006 average exchange rate of 530 pesos per dollar was used. 
Table 2

Descriptive statistics of students that completed $8^{\text {th }}$ grade in a public school and had to switch schools

\begin{tabular}{|c|c|c|c|}
\hline & $\begin{array}{l}\text { 10th grade at } \\
\text { Public School }\end{array}$ & $\begin{array}{l}\text { 10th grade at } \\
\text { Private School }\end{array}$ & t-stat \\
\hline \multirow[t]{2}{*}{ \# schools in student's neighborhood } & 71.173 & 83.468 & -23.07 \\
\hline & (48.644) & $(52.630)$ & \\
\hline \multirow[t]{2}{*}{ \# private schools in student's neighborhood } & 32.018 & 45.459 & -39.22 \\
\hline & (29.774) & $(36.737)$ & \\
\hline \multirow[t]{2}{*}{ Male } & 0.454 & 0.494 & -7.86 \\
\hline & $(0.498)$ & $(0.500)$ & \\
\hline \multirow[t]{2}{*}{ Father's education 8th grade } & 9.424 & 9.923 & -11.82 \\
\hline & $(3.477)$ & $(3.528)$ & \\
\hline \multirow[t]{2}{*}{ Mother's education 8 th grade } & 9.058 & 9.589 & -13.30 \\
\hline & $(3.325)$ & $(3.411)$ & \\
\hline \multirow[t]{2}{*}{ Expectations: technical or professional institute } & 0.325 & 0.349 & -4.75 \\
\hline & $(0.468)$ & $(0.477)$ & \\
\hline \multirow[t]{2}{*}{ Expectations: university } & 0.399 & 0.441 & -8.06 \\
\hline & $(0.490)$ & $(0.497)$ & \\
\hline \multirow[t]{2}{*}{ Family income 8 th grade (divided by 1,000 ) } & 189.151 & 225.525 & -18.66 \\
\hline & $(175.501)$ & $(201.175)$ & \\
\hline \multirow[t]{2}{*}{ Repeated grade } & 0.119 & 0.094 & 7.64 \\
\hline & $(0.324)$ & $(0.291)$ & \\
\hline \multirow[t]{2}{*}{ Attended preschool education } & 0.930 & 0.950 & -7.71 \\
\hline & $(0.256)$ & $(0.219)$ & \\
\hline \multirow[t]{2}{*}{ SIMCE $8^{\text {th }}$ grade math score } & 249.215 & 252.060 & -6.16 \\
\hline & $(44.781)$ & (44.408) & \\
\hline \multirow[t]{2}{*}{ SIMCE $10^{\text {th }}$ grade math score } & 240.599 & 246.230 & -9.21 \\
\hline & (59.407) & $(59.392)$ & \\
\hline \multirow[t]{2}{*}{ SIMCE $8^{\text {th }}$ grade language score } & 249.866 & 252.517 & -5.44 \\
\hline & $(47.137)$ & $(47.258)$ & \\
\hline \multirow[t]{2}{*}{ SIMCE $10^{\text {th }}$ grade language score } & 246.315 & 250.969 & -9.36 \\
\hline & (48.384) & $(48.067)$ & \\
\hline $\mathrm{N}^{\circ}$ observations & 30,621 & 13,674 & \\
\hline
\end{tabular}


Table 3

Probability of attending a private voucher school

(students that completed $8^{\text {th }}$ grade in a public school in 2004)

\begin{tabular}{|c|c|c|c|c|}
\hline & Math & & Language & \\
\hline \multirow[t]{2}{*}{ \# schools in student's neighborhood } & -0.011 & $* * *$ & -0.011 & $* * *$ \\
\hline & $(0.003)$ & & $(0.003)$ & \\
\hline \multirow[t]{2}{*}{ \# private schools in student's neighborhood } & 0.023 & $* * *$ & 0.023 & $* * *$ \\
\hline & $(0.004)$ & & $(0.004)$ & \\
\hline \multirow[t]{2}{*}{ Male } & 0.089 & & 0.088 & \\
\hline & $(0.056)$ & & $(0.056)$ & \\
\hline \multirow[t]{2}{*}{ Father's education 8 th grade } & $3.78 \mathrm{E}-04$ & & $1.32 \mathrm{E}-04$ & \\
\hline & $(0.003)$ & & $(0.003)$ & \\
\hline \multirow[t]{2}{*}{ Mother's education 8th grade } & 0.007 & * & 0.007 & $*$ \\
\hline & $(0.004)$ & & $(0.004)$ & \\
\hline \multirow[t]{2}{*}{ Expectations: technical or professional institute } & 0.109 & $* * *$ & 0.114 & $* * *$ \\
\hline & $(0.029)$ & & $(0.029)$ & \\
\hline \multirow[t]{2}{*}{ Expectations: university } & 0.036 & & 0.042 & \\
\hline & $(0.040)$ & & $(0.040)$ & \\
\hline \multirow[t]{2}{*}{ Family Income 8 th grade (divided by 1,000 ) } & 0.001 & $* * *$ & 0.001 & $* * *$ \\
\hline & (3.19E-04) & & $(3.18 \mathrm{E}-04)$ & \\
\hline \multirow[t]{2}{*}{ Income 8 th grade (divided by 1,000 ) squared } & $-1.22 \mathrm{E}-06$ & $* *$ & $-1.20 \mathrm{E}-06$ & $* *$ \\
\hline & $(5.05 \mathrm{E}-07)$ & & $(5.01 \mathrm{E}-07)$ & \\
\hline \multirow[t]{2}{*}{ Income 8 th grade (divided by 1,000 ) cubed } & $3.64 \mathrm{E}-10$ & $*$ & $3.59 \mathrm{E}-10$ & $*$ \\
\hline & $(2.07 \mathrm{E}-10)$ & & $(2.06 \mathrm{E}-10)$ & \\
\hline \multirow[t]{2}{*}{ Repeated grade } & -0.101 & $* * *$ & -0.100 & $* * *$ \\
\hline & $(0.034)$ & & $(0.034)$ & \\
\hline \multirow[t]{2}{*}{ Attended preschool education } & 0.048 & & 0.051 & \\
\hline & $(0.049)$ & & $(0.049)$ & \\
\hline \multirow[t]{2}{*}{ SIMCE $8^{\text {th }}$ grade math score } & $1.08 \mathrm{E}-04$ & & & \\
\hline & $(4.88 \mathrm{E}-04)$ & & & \\
\hline \multirow[t]{2}{*}{ SIMCE $8^{\text {th }}$ grade language score } & & & 4.61E-05 & \\
\hline & & & $(4.26 \mathrm{E}-04)$ & \\
\hline \multirow[t]{2}{*}{ Constant } & -0.944 & $* * *$ & -0.930 & $* * *$ \\
\hline & $(0.174)$ & & $(0.163)$ & \\
\hline $\mathrm{N}^{\mathrm{o}}$ observations & 27,297 & & 27,212 & \\
\hline Pseudo $\mathrm{R}^{2}$ & 0.057 & & 0.057 & \\
\hline
\end{tabular}

Standard errors in parentheses.

$* * *$ significant at $1 \%, * *$ significant at $5 \%, *$ significant at $10 \%$ 


\section{Table 4}

Students attending public schools in 2004

ATE estimates using propensity scores based methods and validity tests

\begin{tabular}{lcccc}
\hline \multicolumn{1}{c}{ Methodology } & \multicolumn{2}{c}{ Estimated effect } & \multicolumn{2}{c}{ Validity test } \\
\hline & Language & Math & Language & Math \\
\hline Pscore Weighting & $2.8147 * * *$ & $3.0248 * *$ & 0.6461 & 0.7526 \\
& $(0.8280)$ & $(1.4177)$ & $(0.8171)$ & $(0.7605)$ \\
Double-robust & $2.3642 * * *$ & $2.5341 *$ & 0.3626 & 0.5628 \\
& $(0.8458)$ & $(1.3544)$ & $(0.8277)$ & $(0.8054)$ \\
\hline Standard errors in parentheses. ${ }^{* * *}$ significant at $1 \%, * *$ significant at $5 \%, *$ significant at $10 \%$
\end{tabular}


Table 5

Students attending public schools in 2004

Changes-in-Changes results

\begin{tabular}{ccc}
\hline Methodology & \multicolumn{2}{c}{ Estimated effect } \\
\hline CIC without covariates & 1.8725 & 1.8445 \\
& $(2.1725)$ & $(2.9935)$ \\
CIC with covariates & 1.5805 & 1.3373 \\
& $(1.7003)$ & $(2.5057)$ \\
\hline Standard errors in parentheses. & &
\end{tabular}

Table 6

Students attending private voucher schools in 2004

ATE estimates using all methods and validity tests

\begin{tabular}{lcccc}
\hline Methodology & \multicolumn{2}{c}{ ATE } & \multicolumn{2}{c}{ Validity test } \\
\cline { 2 - 5 } & Language & Math & Language & Math \\
\hline \multirow{2}{*}{ Pscore Weighting } & -1.2307 & 1.8094 & $-2.3563 * *$ & $-3.9941 * * *$ \\
& $(1.3063)$ & $(1.8912)$ & $(1.1569)$ & $(1.3694)$ \\
Double-robust & -0.7442 & 2.9750 & $-2.0142 *$ & $-3.4913 * * *$ \\
& $(1.1878)$ & $(1.9056)$ & $(1.1896)$ & $(1.3047)$ \\
CIC without covariates & 0.6080 & 3.4919 & & \\
& $(3.0512)$ & $(4.7378)$ & & \\
CIC with covariates & -0.0139 & 3.4129 & & \\
& $(2.5468)$ & $(3.6701)$ & \\
\hline Standard errors in parentheses. ${ }^{* * *}$ significant at $1 \%, * *$ significant at $5 \%, *$ significant at $10 \%$
\end{tabular}


Figure 1a: Propensity scores by school type, math

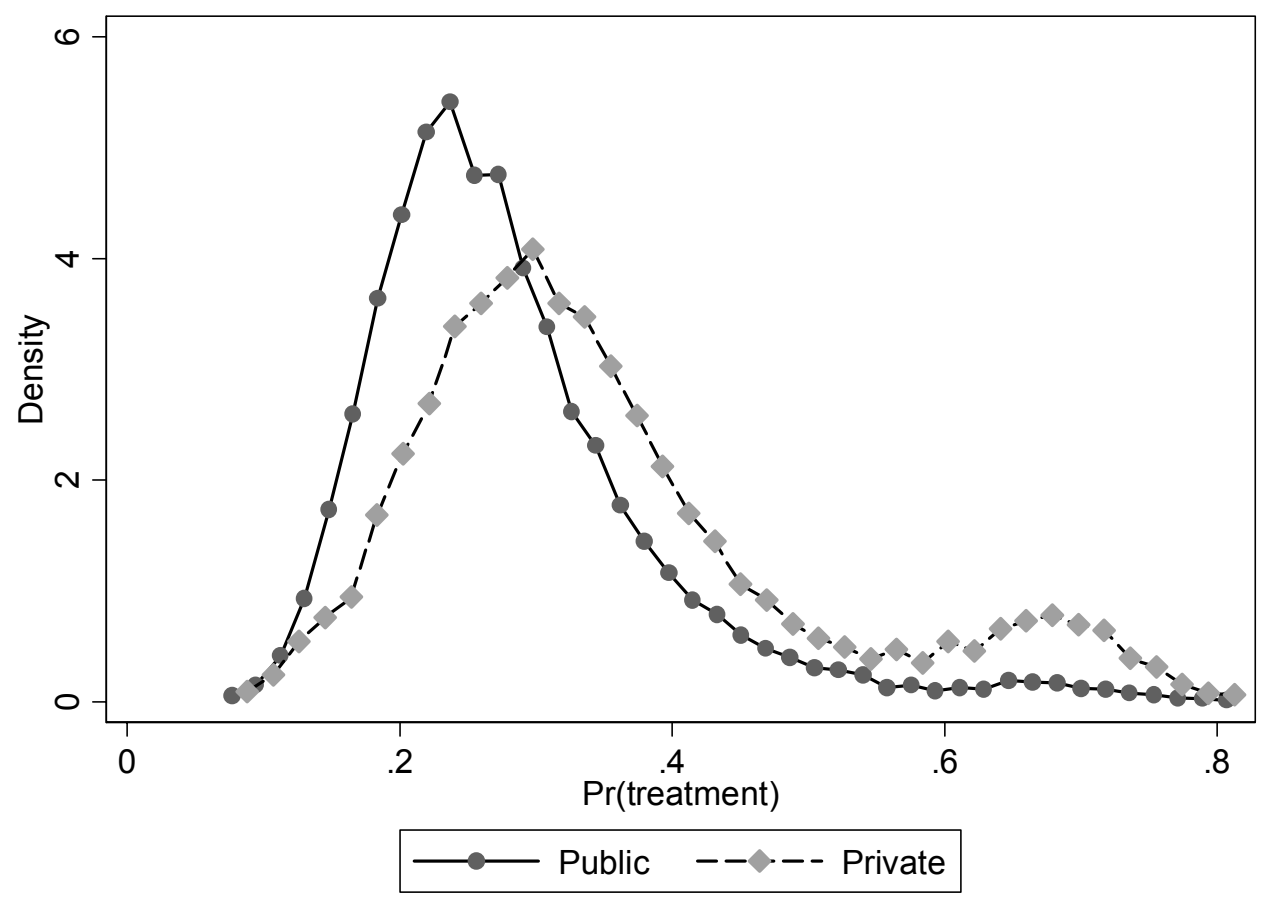

Figure 1b: Propensity scores by school type, language

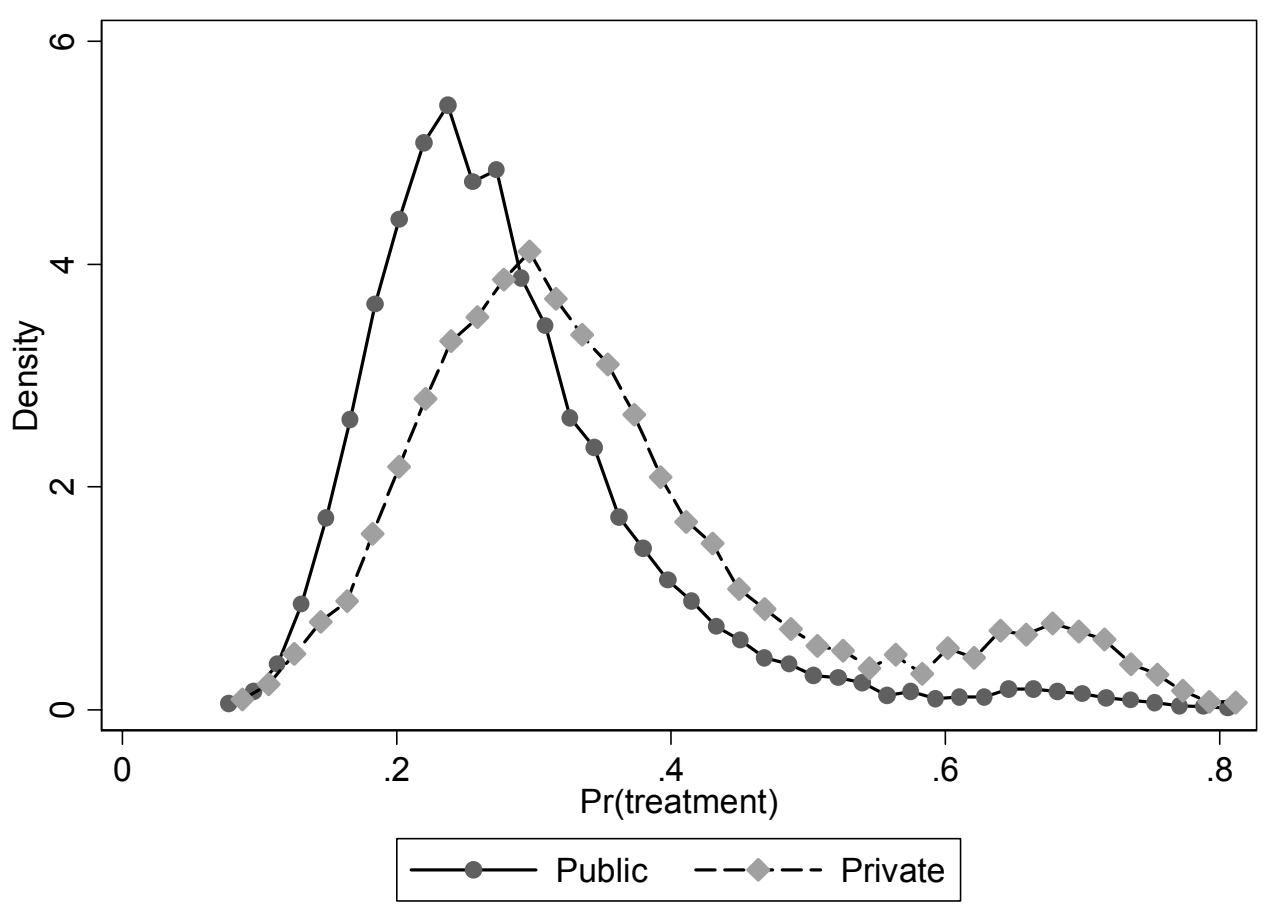


Figure 2a. Effect on students who finish $8^{\text {th }}$ grade at a public school

CIC with covariates along the distribution of $Y$, Math

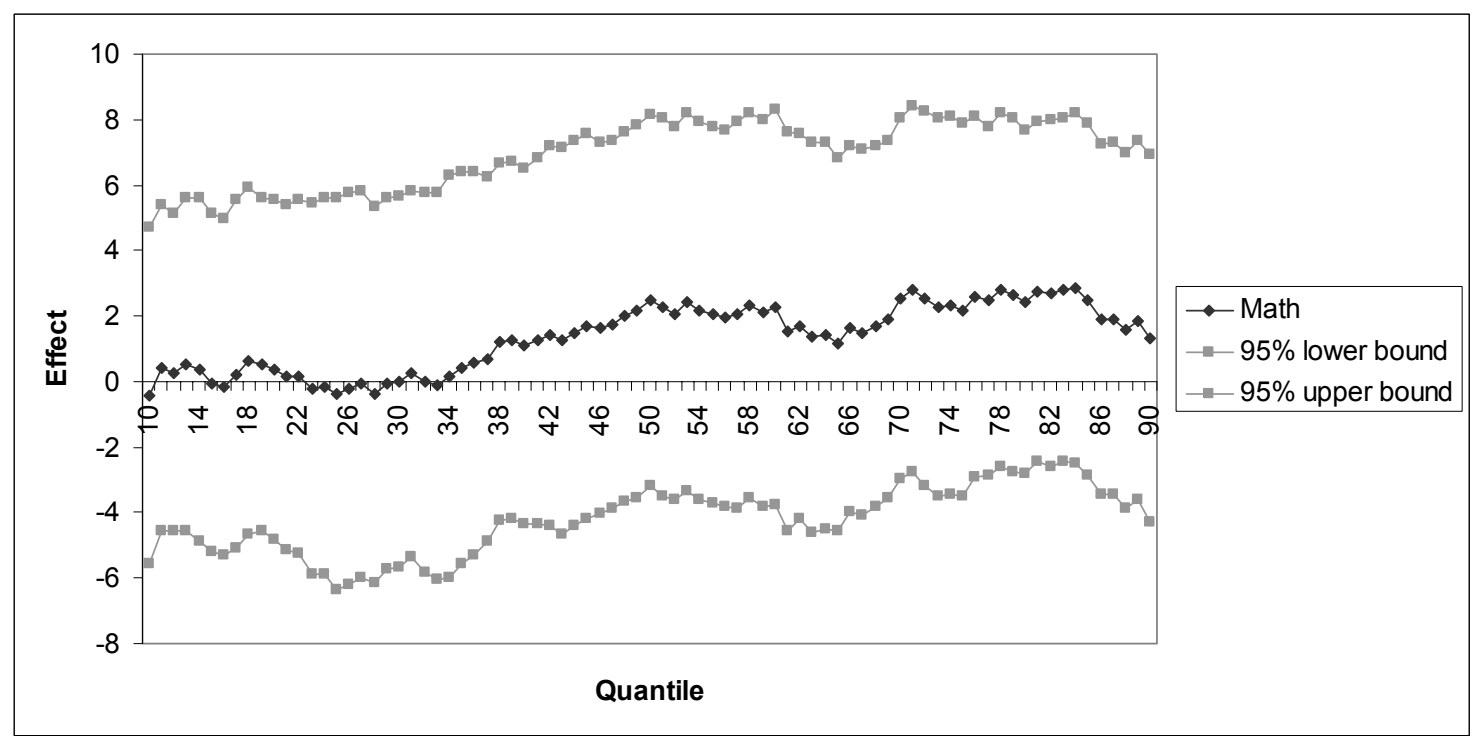

Figure 2 b. Effect on students who finish $8^{\text {th }}$ grade at a public school CIC with covariates along the distribution of $Y$, Language

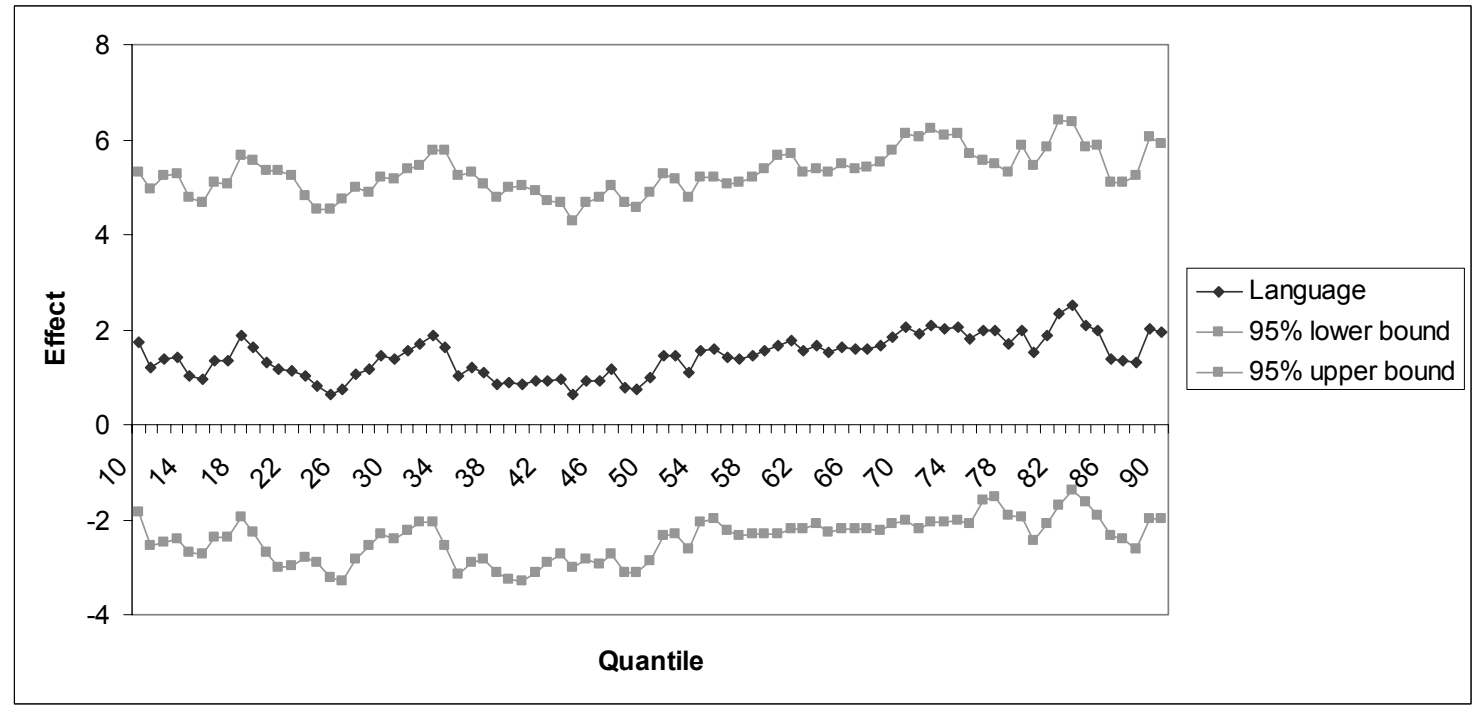


Table A1.

\section{Variables used in the analysis}

\begin{tabular}{|c|c|c|}
\hline Name of Variable & Description & Source \\
\hline Student characteristics & & \\
\hline SIMCE $8^{\text {th }}$ grade math score & Student's score on the math section of the SIMCE 2004 & SIMCE database 2004 \\
\hline SIMCE $8^{\text {th }}$ grade language score & Student's score on the language section of the SIMCE 2004 & SIMCE database 2004 \\
\hline SIMCE $10^{\text {th }}$ grade math score & Student's score on the math section of the SIMCE 2006 & SIMCE database 2006 \\
\hline SIMCE $10^{\text {th }}$ grade language score & Student's score on the language section of the SIMCE 2006 & SIMCE database 2006 \\
\hline \# schools in student's neighborhood & Number of schools in the student's neighborhood of residence 2004 & $\begin{array}{l}\text { Parental questionnaire } 2004 \\
\text { and Ministry of Education }\end{array}$ \\
\hline $\begin{array}{l}\text { \# private schools in student's } \\
\text { neighborhood }\end{array}$ & Number of private schools in the student's neighborhood of residence 2004 & $\begin{array}{l}\text { Parental questionnaire } 2004 \\
\text { and Ministry of Education }\end{array}$ \\
\hline Male & Dummy: 1 if the student is male, 0 if female & Parental questionnaires \\
\hline Father's education 2004 & Number of years of education for the student's father & Parental questionnaires \\
\hline Mother's education 2004 & Number of years of education for the student's mother & Parental questionnaires \\
\hline Expectations: university & Dummy: 1 if the parents expect student to attend college, 0 if not & Parental questionnaires \\
\hline $\begin{array}{l}\text { Expectations: technical or professional } \\
\text { institute }\end{array}$ & $\begin{array}{l}\text { Dummy: } 1 \text { if the parents expect student to attend a technical or professional } \\
\text { institute, } 0 \text { if not }\end{array}$ & Parental questionnaires \\
\hline Income (divided by 1,000 ) & Family income divided by 1,000 pesos & Parental questionnaires \\
\hline Repeated grade & Dummy: 1 if the student has repeated a grade, 0 if not & Parental questionnaire 2004 \\
\hline Preschool & Dummy: 1 if the student attended preschool, 0 if not & Parental questionnaire 2004 \\
\hline $\mathrm{N}^{\circ}$ of books in the students home & Number of books in the student's house & $\begin{array}{l}\text { Parental questionnaire } \\
2004 / 06\end{array}$ \\
\hline $\mathrm{N}^{\circ}$ of people in the students home & Number of people in the student's home & $\begin{array}{l}\text { Parental questionnaire } \\
2004 / 06\end{array}$ \\
\hline School type & School type (0 if public, 1 if private voucher) & SIMCE database \\
\hline
\end{tabular}


Table A2

Descriptive statistics of students that completed $8^{\text {th }}$ grade in a private voucher school and had to switch schools

\begin{tabular}{|c|c|c|c|}
\hline & 10th grade at Public & 10th grade at Private & \\
\hline & School & School & t-stat \\
\hline \multirow[t]{2}{*}{ \# schools in student's neighborhood } & 76.909 & 84.347 & -8.82 \\
\hline & $(50.227)$ & $(52.300)$ & \\
\hline \multirow[t]{2}{*}{ \# private schools in student's neighborhood } & 41.117 & 50.715 & -16.58 \\
\hline & $(33.328)$ & $(36.539)$ & \\
\hline \multirow[t]{2}{*}{ Male } & 0.459 & 0.476 & -2.13 \\
\hline & $(0.498)$ & $(0.499)$ & \\
\hline \multirow[t]{2}{*}{ Father's education 8 th grade } & 10.363 & 10.922 & -8.29 \\
\hline & $(3.510)$ & $(3.565)$ & \\
\hline \multirow[t]{2}{*}{ Mother's education 8th grade } & 10.158 & 10.666 & -7.82 \\
\hline & $(3.464)$ & $(3.421)$ & \\
\hline \multicolumn{4}{|l|}{ Expectations: technical or professional } \\
\hline \multirow[t]{2}{*}{ institute } & 0.275 & 0.309 & -4.51 \\
\hline & $(0.447)$ & $(0.462)$ & \\
\hline \multirow[t]{2}{*}{ Expectations: university } & 0.555 & 0.563 & -1.01 \\
\hline & $(0.497)$ & $(0.496)$ & \\
\hline \multirow[t]{2}{*}{ Income 8 th grade (divided by 1,000 ) } & 234.390 & 284.815 & -13.61 \\
\hline & $(203.333)$ & $(241.913)$ & \\
\hline \multirow[t]{2}{*}{ Repeated grade } & 0.084 & 0.069 & 3.67 \\
\hline & $(0.278)$ & $(0.253)$ & \\
\hline \multirow[t]{2}{*}{ Attended preschool education } & 0.962 & 0.973 & -3.87 \\
\hline & $(0.191)$ & $(0.162)$ & \\
\hline \multirow[t]{2}{*}{ SIMCE $8^{\text {th }}$ grade math score } & 263.925 & 263.623 & 0.41 \\
\hline & $(48.385)$ & $(46.062)$ & \\
\hline \multirow[t]{2}{*}{ SIMCE $10^{\text {th }}$ grade math score } & 257.114 & 260.256 & -3.22 \\
\hline & $(63.505)$ & $(60.559)$ & \\
\hline \multirow[t]{2}{*}{ SIMCE $8^{\text {th }}$ grade language score } & 263.207 & 263.547 & -0.45 \\
\hline & $(49.141)$ & $(47.349)$ & \\
\hline \multirow[t]{2}{*}{ SIMCE $10^{\text {th }}$ grade language score } & 259.967 & 260.893 & -1.19 \\
\hline & $(49.968)$ & $(48.545)$ & \\
\hline $\mathrm{N}^{\mathrm{o}}$ observations & 6,550 & 10,260 & \\
\hline
\end{tabular}


Table A3

\section{Descriptive statistics of all students that completed $8^{\text {th }}$ grade and had to switch}

schools

\begin{tabular}{|c|c|c|c|}
\hline & 10th grade at Public & 10th grade at Private & \\
\hline & School & School & t-stat \\
\hline \multirow[t]{2}{*}{ \# schools in student's neighborhood } & 72.184 & 83.847 & -26.94 \\
\hline & $(48.975)$ & $(52.489)$ & \\
\hline \multicolumn{4}{|l|}{ \# private schools in student's } \\
\hline \multirow[t]{2}{*}{ neighborhood } & 33.622 & 47.727 & -49.50 \\
\hline & $(30.627)$ & $(36.743)$ & \\
\hline \multirow[t]{2}{*}{ Male } & 0.455 & 0.486 & -7.67 \\
\hline & $(0.498)$ & $(0.500)$ & \\
\hline \multirow[t]{2}{*}{ Father's education 8th grade } & 9.583 & 10.338 & -21.80 \\
\hline & $(3.500)$ & $(3.577)$ & \\
\hline \multirow[t]{2}{*}{ Mother's education 8th grade } & 9.242 & 10.030 & -23.84 \\
\hline & $(3.374)$ & $(3.456)$ & \\
\hline \multicolumn{4}{|l|}{ Expectations: technical or professional } \\
\hline \multirow[t]{2}{*}{ institute } & 0.316 & 0.332 & -3.85 \\
\hline & $(0.465)$ & $(0.471)$ & \\
\hline \multirow[t]{2}{*}{ Expectations: university } & 0.426 & 0.493 & -15.69 \\
\hline & $(0.495)$ & $(0.500)$ & \\
\hline \multirow[t]{2}{*}{ Income 8 th grade (divided by 1,000 ) } & 197.135 & 251.005 & -31.83 \\
\hline & $(181.543)$ & $(221.558)$ & \\
\hline \multirow[t]{2}{*}{ Repeated grade } & 0.113 & 0.083 & 11.70 \\
\hline & $(0.316)$ & $(0.276)$ & \\
\hline \multirow[t]{2}{*}{ Attended preschool education } & 0.935 & 0.960 & -12.52 \\
\hline & $(0.246)$ & $(0.197)$ & \\
\hline \multirow[t]{2}{*}{ SIMCE $8^{\text {th }}$ grade math score } & 251.813 & 257.021 & -13.70 \\
\hline & $(45.782)$ & $(45.486)$ & \\
\hline \multirow[t]{2}{*}{ SIMCE $10^{\text {th }}$ grade math score } & 243.509 & 252.243 & -17.43 \\
\hline & $(60.476)$ & $(60.295)$ & \\
\hline \multirow[t]{2}{*}{ SIMCE $8^{\text {th }}$ grade language score } & 252.220 & 257.250 & -12.67 \\
\hline & $(47.767)$ & $(47.610)$ & \\
\hline \multirow[t]{2}{*}{ SIMCE $10^{\text {th }}$ grade language score } & 248.718 & 255.221 & -16.07 \\
\hline & $(48.942)$ & $(48.520)$ & \\
\hline $\mathrm{N}^{o}$ observations & 37,171 & 23,934 & \\
\hline
\end{tabular}


Table A4

Probability of attending a private voucher school for validity tests (students that completed $8^{\text {th }}$ grade in a public school in 2004)

\begin{tabular}{|c|c|c|}
\hline & Coeff. & \\
\hline \# schools in student's neighborhood & $\begin{array}{l}-0.011 \\
(0.001)\end{array}$ & $* * *$ \\
\hline \# private schools in student's neighborhood & $\begin{array}{c}0.023 \\
(0.002)\end{array}$ & $* * *$ \\
\hline Male & $\begin{array}{c}0.090 \\
(0.025)\end{array}$ & $* * *$ \\
\hline Father's education 8 th grade & $\begin{array}{c}1.97 \mathrm{E}-04 \\
(0.003)\end{array}$ & \\
\hline Mother's education 8th grade & $\begin{array}{c}0.007 \\
(0.003)\end{array}$ & $* *$ \\
\hline Expectations: technical or professional institute & $\begin{array}{c}0.110 \\
(0.024)\end{array}$ & $* * *$ \\
\hline Expectations: university & $\begin{array}{c}0.040 \\
(0.028)\end{array}$ & \\
\hline Family Income 8 th grade (divided by 1,000 ) & $\begin{array}{c}0.001 \\
(2.18 \mathrm{E}-04)\end{array}$ & $* * *$ \\
\hline Income 8 th grade (divided by 1,000 ) squared & $\begin{array}{l}-1.20 \mathrm{E}-06 \\
(4.00 \mathrm{E}-07)\end{array}$ & $* * *$ \\
\hline Income 8th grade (divided by 1,000 ) cubed & $\begin{array}{c}3.58 \mathrm{E}-10 \\
(1.72 \mathrm{E}-10)\end{array}$ & $* *$ \\
\hline Repeated grade & $\begin{array}{l}-0.104 \\
(0.030)\end{array}$ & $* * *$ \\
\hline Attended preschool education & $\begin{array}{c}0.048 \\
(0.041)\end{array}$ & \\
\hline Constant & $\begin{array}{c}-0.918 \\
(0.068)\end{array}$ & $* * *$ \\
\hline $\mathrm{N}^{\mathrm{o}}$ observations & 27,338 & \\
\hline Pseudo $\mathrm{R}^{2}$ & 0.057 & \\
\hline
\end{tabular}

Standard errors in parentheses.

$* * *$ significant at $1 \%, * *$ significant at $5 \%, *$ significant at $10 \%$ 
Table A5

Probability of attending a private voucher school

(Students that completed $8^{\text {th }}$ grade in a private voucher school in 2004)

\begin{tabular}{|c|c|c|c|c|}
\hline & Math & & Language & \\
\hline \multirow[t]{2}{*}{ \# schools in student's neighborhood } & -0.010 & $* * *$ & -0.010 & $* *$ \\
\hline & $(0.003)$ & & $(0.003)$ & \\
\hline \multirow[t]{2}{*}{ \# private schools in student's neighborhood } & 0.019 & $* * *$ & 0.019 & $* * *$ \\
\hline & $(0.005)$ & & $(0.005)$ & \\
\hline \multirow[t]{2}{*}{ Male } & 0.048 & & 0.030 & \\
\hline & $(0.081)$ & & $(0.084)$ & \\
\hline \multirow[t]{2}{*}{ Father's education 8 th grade } & 0.009 & $*$ & 0.008 & \\
\hline & $(0.005)$ & & $(0.005)$ & \\
\hline \multirow[t]{2}{*}{ Mother's education 8th grade } & 0.011 & $*$ & 0.011 & $*$ \\
\hline & $(0.006)$ & & $(0.006)$ & \\
\hline \multirow[t]{2}{*}{ Expectations: technical or professional institute } & 0.088 & $*$ & 0.092 & $*$ \\
\hline & $(0.049)$ & & $(0.048)$ & \\
\hline \multirow[t]{2}{*}{ Expectations: university } & -0.011 & & -0.014 & \\
\hline & $(0.072)$ & & $(0.072)$ & \\
\hline \multirow[t]{2}{*}{ Income 8 th grade (divided by 1,000 ) } & 0.002 & $* * *$ & 0.002 & $* * *$ \\
\hline & $(4.16 \mathrm{E}-04)$ & & $(4.16 \mathrm{E}-04)$ & \\
\hline \multirow[t]{2}{*}{ Income 8 th grade (divided by 1,000 ) squared } & $-1.56 \mathrm{E}-06$ & $* *$ & $-1.53 \mathrm{E}-06$ & $* *$ \\
\hline & $(6.32 \mathrm{E}-07)$ & & $(6.32 \mathrm{E}-07)$ & \\
\hline \multirow[t]{2}{*}{ Income 8 th grade (divided by 1,000 ) cubed } & 4.9E-10 & $*$ & $4.81 \mathrm{E}-10$ & $*$ \\
\hline & $(2.56 \mathrm{E}-10)$ & & $(2.56 \mathrm{E}-10)$ & \\
\hline \multirow[t]{2}{*}{ Repeated grade } & -0.099 & $*$ & -0.091 & $*$ \\
\hline & $(0.055)$ & & $(0.055)$ & \\
\hline \multirow[t]{2}{*}{ Attended preschool education } & 0.026 & & 0.031 & \\
\hline & $(0.092)$ & & $(0.092)$ & \\
\hline \multirow[t]{2}{*}{ SIMCE $8^{\text {th }}$ grade math score } & $-9.24 \mathrm{E}-04$ & & & \\
\hline & $(7.29 \mathrm{E}-04)$ & & & \\
\hline \multirow[t]{2}{*}{ SIMCE $8^{\text {th }}$ grade language score } & & & $-5.322 \mathrm{E}-04$ & \\
\hline & & & $(6.13 \mathrm{E}-04)$ & \\
\hline \multirow[t]{2}{*}{ Constant } & -0.116 & & -0.211 & \\
\hline & $(0.261)$ & & $(0.243)$ & \\
\hline $\mathrm{N}^{\mathrm{o}}$ observations & 9,772 & & 9,724 & \\
\hline Pseudo $\mathrm{R}^{2}$ & 0.047 & & 0.046 & \\
\hline
\end{tabular}

